\title{
Cultivating Coffee Experiences in the Eje Cafetero, Colombia
}

\begin{abstract}
Purpose: The paper investigates the potential for developing a unique coffee tourism experience in the Eje Cafetero region of Colombia, considering unique local traditions of coffee production, as well as local tourism infrastructure.
\end{abstract}

Design/methodology/approach: With the aim of observing coffee tourism experiences inplace, the paper uses an analytical auto-ethnographic methodology, where the researcher observes the coffee tourism experience, considering both the tourism providers and tourists. This represents an emerging method in tourism research, with data collected through a reflective diary and photographic documentation.

Findings: Coffee tourism has already established itself in the Eje Cafetero region, and with increasing tourism in Colombia, there is potential for further interest in coffee tourism in the region. With an established infrastructure and positive reputation for coffee, Colombia is well placed to provide various coffee tourism offerings, including unique experiences based on local traditions.

Originality: Coffee tourism is an under-researched area, with few studies based on primary data to understand the potential for coffee tourism experiences. This study advances knowledge on this, while also promoting innovative auto-ethnographic research methods. Findings help places understand how to leverage competitive advantage through unique offerings.

Keywords: Coffee tourism, tourism marketing, Colombia, Auto-ethnography 


\section{Introduction}

Coffee is one of the most consumed drinks worldwide. Coffee culture has grown in popularity recently, and is a central aspect of cultures, identities and livelihoods across the world (Everett, 2016). Global coffee consumption has increased from 146.98 million $60 \mathrm{~kg}$ bags in 2012/13 to 165.35 million in 2018/19 (Statista, 2020). However, coffee is more than a drink, it represents a significant part of the economy for many coffee-producing countries, largely Global South countries. Brazil is the largest producer, making 61.7 million $60 \mathrm{~kg}$ bags in 2018, followed by Vietnam (29.5 million), with Colombia third (14.2 million) (Statista, 2019).

Many of the largest coffee-producing countries are in South America, Africa and Asia (Statista, 2019), areas where tourism is increasing (UNWTO, 2020). Food tourism is a significant aspect of tourism, as food represents an important part of the cultural heritage of a place, and the various traditions and forms of coffee lead to unique coffee experiences associated with places (Thorn \& Segal, 2007). This aligns with the concept of terroir, often associated with French wines, that foods have unique characteristics of place according to the climate, soil, topography or local traditions (Barham, 2003). Coffee derived from different places possesses different characteristics according to the way it is produced, therefore providing coffeeproducing places with unique offerings. Additionally, the cultural heritage of coffee to certain places is expressed in traditional coffee-making ceremonies in Ethiopia, associated with indigenous identity (Lyon, 2013), or Arab coffeehouse culture, as places where people meet (Yılmaz et al., 2017).

Whereas extensive literature exists on food tourism experiences (such as Everett, 2016; Sims, 2009), this is largely seen from the perspective of wine, and the focus on coffee experiences is limited. Within the existing literature it is recognised that the cultural and geographic heritage of coffee can be exploited by places to offer tourists unique experiences, with this offering increasingly evident through coffee tours and experiences that highlight the coffee terroir of the place (Lyon, 2013). Despite the potential for coffee tourism, few destinations have realised this potential (Kleidas \& Jolliffe, 2010), with coffee tourism considered less prominent than wine tourism. Coffee tourism remains a relatively under-researched area (with the exception of Jolliffe, 2010; Kleidas \& Jolliffe, 2010; Lyon, 2013). Therefore, this paper aims to contribute to coffee tourism research by investigating unique experiential coffee tourism offerings in Colombia, differing from previous research by analysing primary data from an auto-ethnographic study observing coffee tourism experiences. The aim is to contribute to knowledge of auto-ethnography as a method gaining traction in tourism research. Colombia is the third largest coffee-producing country in the world (Statista, 2019), and increasingly appealing to tourists, with international visitor numbers increasing from 557,000 in 2000, to 3.9 million in 2018 (World Bank, 2020). Coffee is one of the cultural aspects known about Colombia on a global scale, and the Eje Cafetero ('Coffee Axis') is an area that is a destination on many tourism routes around the country.

Using Resource-based View (RBV) theory, this paper considers the coffee tourism offer of the Eje Cafetero region, and how this could appeal to potential tourists. Following an exploratory auto-ethnographic study, this research aims to address the main research question: to what extent does the coffee tourism offering of the Eje Cafetero region represent a unique 
experience? Additionally, this paper explores the value of auto-ethnography as a method in tourism research. The following section presents a discussion of literature relating to tourism experiences and place associations of foods. After this, the auto-ethnographic methodology is outlined, before the findings are presented, analysed and discussed with the aim of drawing suitable conclusions.

\section{Literature Review}

Food tourism encompasses a variety of different aspects, as underlined in the definition by Hall and Sharples (2004, p. 10): "visitation to primary and secondary food producers, food festivals, restaurants and specific locations for which food tasting and/or experiencing the attributes of specialist food production region are the primary motivating factor for travel". Although a gradually emerging field, coffee tourism remains under-researched within food tourism, with the majority of research on wine (Getz \& Brown, 2006) or beer (Bujdosó \& Szûcs, 2012) tourism. Notable exceptions include Jolliffe (2010), who offers a comprehensive overview of coffee tourism, and Everett (2016), who includes various examples and case studies. Beverage tourism, as with other areas of food tourism, is influenced by the visitor travelling for the drink experience or the product (Plummer et al., 2005), however, various forms of tourism experiences have been expressed in the literature. Bujdosó and Szûcs (2012) point to beer or place as motivators for beer tourism, where the beer motivator includes tastings, routes, or beer weekends, and the place includes festivals, museums, or brasseries. Visits to vineyards and tastings are key aspects of wine tourism, however Getz and Brown (2006) recognise wine tourism as a secondary activity for wine producers, a way to supplement their wine production activity. Although visiting vineyards is a means to educate visitors and raise awareness of wines, Everett (2016) recognises its potential as a place identifier, developing a region's identity.

The varied types of food tourism experiences are further expressed by Jolliffe (2010), who distinguishes coffee destinations into three categories: coffee-producing destinations (such as Colombia), coffee culture destinations (such as Seattle, home of Starbucks), or coffee history destinations (such as Vienna). Compared to tea, whisky and beer, Everett (2016) outlines the main coffee tourism activities as factory tours, plantation visits, coffee routes, museums, coffee shops, and the purchase of coffee equipment. Kleidas and Joliffe (2010) note that the nature of coffee tourism experiences sought by visitors depends on their preferences in coffee consumption, which can vary greatly among consumers, acknowledging tourists' interest in authentic coffee experiences. Similarly, increased demand is observed for speciality coffee as a distinction from large multinational coffee chains, with interest in the origin and quality of coffee products (Oberthür et al., 2011). Kleidas and Joliffe (2010) acknowledge that coffee tourism offers opportunities for growth in peripheral regions, especially the Global South. Woyesa and Kumar (2020) document the potential for coffee tourism in Ethiopia, recognised as the origin of coffee, with a view to developing sustainability in respect to local livelihoods and conservation. Focussing on Guatemala, Lyon (2013) points to benefits of coffee tourism to local communities, with an affirmation of indigenous identity, but warns of disadvantages of an over-reliance on tourism, advocating cooperation among local tourism providers. Anbalagan and Lovelock (2014) recognise the potential for coffee 
tourism to benefit local communities in Rwanda, but emphasise the need for confidencebuilding within local coffee-producing communities to overcome many barriers to coffee tourism. These include the country's image following a well-documented period of conflict, its reputation for coffee, and tourism infrastructure in Rwanda.

Food is considered a cultural experience, to which authenticity is significant (Ellis et al., 2018). There are deep-rooted connections between food and place, with foods acting as strong indicators of heritage, traditions and authenticity of a place (Tregear et al., 1998). An example is the Cornish pasty, a dish traditionally consumed by mine workers with meat in one end and jam in the other, representing cultural heritage and customs of food to place (Bowen \& Bennett, 2020). Connections between food and place are also evident in protected food names, including Protected Designation of Origin (PDO) or Protected Geographical Indication (PGI), providing intellectual property rights to designated products (Tregear et al., 2015). Examples include Parma Ham, Champagne, or Stilton Cheese. These geographical indications provide protection to unique local food identities from imitation products. Colombian Coffee obtained a PGI status in 2007, the first non-EU product to receive protected status, as part of national policy initiatives to protect and market the unique qualities of Colombian coffee (Oberthür et al., 2011).

Grounded in RBV theory (Barney, 1991; Teece 2007), unique food-territory associations can be exploited for economic or marketing purposes to differentiate or add value to products to gain competitive advantage. This can be developed for food tourism destinations (Knollenberg et al., 2020). Considering the VRIN model (Barney, 1991), the unique characteristics of foods associated with terroir represent valuable, rare, inimitable and nonsubstitutable attributes specific to place, which distinguish the foods of that place from similar foods elsewhere. This is evident in products with protected food names, as food characteristics are protected (Tregear et al., 2015), such as Colombian coffee. Coffee is a product inextricably linked to place (Thorn \& Segal, 2007), pointing to the various styles of coffee evident around the world as a culinary experience for consumption in place. RBV theory aligns with similar research on place-based competitiveness in the context of Latin American countries (cf. Diaz Hermelo \& Vassolo, 2012; Jardón \& Martos, 2012; Jardón \& Tañski, 2018). Place is an important source of competitive advantage among subsistence small businesses in Argentina based on place resources (Jardón \& Tañski, 2018), however, it is noted that macroeconomic conditions in Latin American countries can be volatile, therefore distinctions are observed with developed countries (Diaz Hermelo \& Vassolo, 2012).

Globalisation has caused a homogenisation of place (Cresswell, 2004) and a placelessness (Relph, 1976) where many places resemble each other. This is akin to Ritzer's (1992) McDonaldization of Society, and the presence of large international chains, such as McDonald's or Starbucks, across the world. Molleda and Roberts (2008) document nation branding activities in Colombia to strengthen the image and brand of Colombian coffee through a Colombian chain of coffee shops, Juan Valdez. Since its inception in 2002, the chain is present in 13 countries worldwide (Juan Valdez, 2020). The Juan Valdez brand supports the Colombian coffee culture, underlining its authenticity (Muñiz Martínez, 2016). Authenticity is significant in food tourism, as tourists seek 'otherness' (MacCannell, 1973) and alternatives 
to homogenisation (Ellis et al., 2018). Given the traditions, symbols and heritage of food and place, tourists can engage in cultural experiences of place through local food. Destinations are increasingly aware of the significance of local food within tourism strategies (Du Rand \& Heath, 2006), including experiences developed by local food producers (Broadway, 2017).

\section{Methodology}

Given limited research on coffee tourism experiences, this research takes an exploratory approach to discover opportunities for developing coffee tourism experiences in the Eje Cafetero. The region, situated in mid-western Colombia, is part of the Paisaje Cultural Cafetero ('Coffee Cultural Landscape'), inscribed on the UNESCO World Heritage List in 2011. Colombia was chosen as the research setting as an emerging tourism destination, with nearly 4 million visitors to the country in 2018 (World Bank, 2020), and a country known worldwide for producing coffee.

Based on a pragmatist viewpoint, the researcher's epistemology is centred on practical research, believing strongly in the 'what works' principle (Creswell \& Plano Clark, 2011). As this research investigates experiences of coffee tourism, auto-ethnography was considered appropriate, where the researcher documents the experiences of visiting a coffee farm. Autoethnography is emerging within Tourism research as a valuable methodology, encouraged widely by Scarles (2010) or Shepherd et al. (2020), following calls by Tribe (2004) for 'new' research using appropriate methodologies. Auto-ethnography enables the researcher to take an active role in the process, becoming a subject of the research (Scarles, 2010). Given the focus here on understanding tourism experiences, the placement of the researcher in the tourism experience allows for a richer understanding of this experience and how it is lived. The evaluation of this lived experience was a reason for adoption of this method over more widely-used methods, such as interviews. This follows a similar approach to Shepherd et al. (2020) who conducted evocative auto-ethnographic research of a visit to Bethlehem, Palestine. As a relatively new method, robust research is sought through an analytical autoethnographic method (Anderson, 2006), where the researcher is committed to developing theoretical understandings of broader social phenomena. Rigour is further considered through collecting a variety of data including a reflective diary, photographic documentation and written accounts of conversations with tourism providers and tourists during the visit.

Research was based on the experience of the researcher visiting a coffee finca (farm) near Salento in the Eje Cafetero region in August 2019. The day visit was organised by a hotel in Salento, which had developed a partnership with this finca. As one of a number of coffee tours in the local area, this visit was advertised as a more personalised experience due to the small scale of the finca, the limited number of visitors permitted on the tour (four) and the engagement of the finca owner, who was present throughout the whole experience. Observations were made of the researcher's experience as a tourist on the finca, as well as three other tourists, and the role of the finca owner as the guide for the visit, conducted in Spanish. Conversations between the researcher and finca owner were conducted in Spanish, with conversations in English between the researcher and other tourists. The coffee tourism experience involved learning about the entire coffee production process, based on the traditional method of this finca, typical of the local area; beginning by picking the coffee fruit, 
through to the grinding of the coffee beans. The experience included a typical local lunch and ended by tasting freshly-produced coffee.

While a reflective diary and field notes are established forms of data collection in ethnography, the use of photography is emerging as an acceptable method in Tourism research (cf. Garrod, 2007; Scarles, 2010). Pink (2013) identifies visuals as one of the most persuasive and pervasive sources of human sensorial experience. Visual representations have an important relationship with words in knowledge creation and theoretical discussion (Pink, 2006). Data from this experience was gathered through a reflective diary written by the researcher immediately after the day experience, 97 were photographs taken by the researcher to document the entire experience, and written accounts of conversations between the finca owner and other tourists during the day. All written data was documented in English, with written and visual data stored and coded in NVivo12. Thematic analysis was used to identify relevant themes following the six step process of Braun and Clarke (2006). Text and photo data were analysed separately following the same process, firstly generating codes, which were subsequently grouped into themes.

\section{Findings}

Data was based on observations of five actors involved in the tourism experience, including the coffee producer leading the visit, a local tourism provider who accompanied tourists to the farm, and three tourists.

\subsection{Text data}

Text data included the reflective diary written by the researcher and written accounts of conversations conducted with the tourism providers and tourists, based on notes taken during the visit. Formal interviews were not conducted during the process to not disrupt the tourism experience, as the aim was to observe the tourism providers and tourists during the experience. The coding process generated 154 codes, which equated to 46 individual codes. This led to the formulation of seven themes (Table 1), notably coffee experience, coffee production process, community, place, sustainability, tourism experience and tourism infrastructure.

Table 1: Themes from text data

\begin{tabular}{|l|l|l|l|l|l|l|}
\hline $\begin{array}{l}\text { Coffee } \\
\text { experience }\end{array}$ & $\begin{array}{l}\text { Coffee } \\
\text { production } \\
\text { process }\end{array}$ & Community & Place & Sustainability & $\begin{array}{l}\text { Tourism } \\
\text { experience }\end{array}$ & $\begin{array}{l}\text { Tourism } \\
\text { infrastructure }\end{array}$ \\
\hline $\begin{array}{l}\text { Coffee } \\
\text { products }\end{array}$ & $\begin{array}{l}\text { Picking } \\
\text { coffee fruit }\end{array}$ & $\begin{array}{l}\text { Contributing } \\
\text { to the local } \\
\text { economy }\end{array}$ & $\begin{array}{l}\text { Coffee farm } \\
\text { Scenery }\end{array}$ & $\begin{array}{l}\text { Coffee } \\
\text { tourism } \\
\text { motivated by } \\
\text { sustainability }\end{array}$ & $\begin{array}{l}\text { Ability to } \\
\text { speak } \\
\text { Spanish (or } \\
\text { not) }\end{array}$ & $\begin{array}{l}\text { Accessing the } \\
\text { area }\end{array}$ \\
\hline $\begin{array}{l}\text { Coffee } \\
\text { tasting }\end{array}$ & $\begin{array}{l}\text { De-pulping } \\
\text { the fruit }\end{array}$ & $\begin{array}{l}\text { Cultural } \\
\text { enrichment } \\
\text { from } \\
\text { welcoming } \\
\text { tourists }\end{array}$ & $\begin{array}{l}\text { Tourist } \\
\text { destination }\end{array}$ & Composting & $\begin{array}{l}\text { Coffee tour } \\
\text { information } \\
\text { in the hotel }\end{array}$ & $\begin{array}{l}\text { Improving } \\
\text { tourism } \\
\text { infrastructure }\end{array}$ \\
\hline
\end{tabular}




\begin{tabular}{|c|c|c|c|c|c|c|}
\hline $\begin{array}{l}\text { Complete } \\
\text { coffee } \\
\text { experience }\end{array}$ & $\begin{array}{l}\text { Drying the } \\
\text { coffee } \\
\text { beans }\end{array}$ & $\begin{array}{l}\text { Influx of } \\
\text { tourism } \\
\text { providers } \\
\text { pushes up } \\
\text { prices locally }\end{array}$ & $\begin{array}{l}\text { Traditional } \\
\text { local food }\end{array}$ & Conservation & $\begin{array}{l}\text { Providing a } \\
\text { unique } \\
\text { tourism } \\
\text { offering }\end{array}$ & $\begin{array}{l}\text { Majority of } \\
\text { the tourism } \\
\text { infrastructure } \\
\text { owned by } \\
\text { non-locals }\end{array}$ \\
\hline $\begin{array}{l}\text { Educational } \\
\text { experience }\end{array}$ & $\begin{array}{l}\text { Grinding } \\
\text { the coffee } \\
\text { beans }\end{array}$ & $\begin{array}{l}\text { Local } \\
\text { community }\end{array}$ & $\begin{array}{l}\text { Unique } \\
\text { coffee taste }\end{array}$ & $\begin{array}{l}\text { Ecological } \\
\text { awareness }\end{array}$ & $\begin{array}{l}\text { Unique } \\
\text { tourism } \\
\text { experience }\end{array}$ & $\begin{array}{l}\text { Other local } \\
\text { farms have } \\
\text { better } \\
\text { resources }\end{array}$ \\
\hline $\begin{array}{l}\text { Filtering the } \\
\text { coffee }\end{array}$ & $\begin{array}{l}\text { Removing } \\
\text { the shells }\end{array}$ & $\begin{array}{l}\text { Local } \\
\text { partnerships } \\
\text { with tourism } \\
\text { providers }\end{array}$ & & Nature & & $\begin{array}{l}\text { Other local } \\
\text { farms owned } \\
\text { by non-locals }\end{array}$ \\
\hline $\begin{array}{l}\text { Interactive } \\
\text { experience }\end{array}$ & $\begin{array}{l}\text { Roasting } \\
\text { the coffee } \\
\text { beans }\end{array}$ & $\begin{array}{l}\text { Need to } \\
\text { diversify into } \\
\text { tourism for } \\
\text { livelihood }\end{array}$ & & $\begin{array}{l}\text { Organic } \\
\text { process }\end{array}$ & & \\
\hline $\begin{array}{l}\text { Traditional } \\
\text { coffee farm }\end{array}$ & $\begin{array}{l}\text { Passion for } \\
\text { traditional } \\
\text { coffee } \\
\text { production } \\
\text { methods }\end{array}$ & $\begin{array}{l}\text { Need to take } \\
\text { advantage of } \\
\text { tourists in } \\
\text { the local } \\
\text { area }\end{array}$ & & $\begin{array}{l}\text { Self- } \\
\text { sustainability }\end{array}$ & & \\
\hline \multirow[t]{2}{*}{$\begin{array}{l}\text { Traditional } \\
\text { equipment }\end{array}$} & $\begin{array}{l}\text { Traditional } \\
\text { coffee } \\
\text { farming } \\
\text { methods }\end{array}$ & $\begin{array}{l}\text { Sustainable } \\
\text { tourism } \\
\text { needed to } \\
\text { maintain } \\
\text { livelihoods }\end{array}$ & & & & \\
\hline & & $\begin{array}{l}\text { Tourism } \\
\text { earnings } \\
\text { leaving the } \\
\text { area }\end{array}$ & & & & \\
\hline
\end{tabular}

\subsection{Photo Data}

A total of 97 photographs were taken by the researcher during the entire visit. Photographs were uploaded to NVivo12, with the coding process generating 452 codes, equating to 35 individual codes. This led to six themes (Table 2 ), namely coffee experience, coffee farm, coffee production process, place, sustainability and tourism experience.

Table 2: Themes from photo data

\begin{tabular}{|l|l|l|l|l|l|}
\hline $\begin{array}{l}\text { Coffee } \\
\text { experience }\end{array}$ & Coffee farm & $\begin{array}{l}\text { Coffee } \\
\text { production } \\
\text { process }\end{array}$ & Place & Sustainability & $\begin{array}{l}\text { Tourism } \\
\text { experience }\end{array}$ \\
\hline $\begin{array}{l}\text { Preparing to } \\
\text { drink the coffee }\end{array}$ & $\begin{array}{l}\text { Coffee farm } \\
\text { infrastructure }\end{array}$ & $\begin{array}{l}\text { Picking coffee } \\
\text { fruit }\end{array}$ & $\begin{array}{l}\text { Zona } \\
\text { Cafetera }\end{array}$ & $\begin{array}{l}\text { Sustainable } \\
\text { practice }\end{array}$ & $\begin{array}{l}\text { Traditional } \\
\text { food }\end{array}$ \\
\hline Demonstration & Plants & $\begin{array}{l}\text { De-pulping } \\
\text { coffee fruit }\end{array}$ & Salento & Composting & $\begin{array}{l}\text { Tourist } \\
\text { experience }\end{array}$ \\
\hline $\begin{array}{l}\text { Group } \\
\text { enjoyment }\end{array}$ & Rustic & $\begin{array}{l}\text { Drying the } \\
\text { beans }\end{array}$ & Rural & $\begin{array}{l}\text { Planting new } \\
\text { coffee plants }\end{array}$ & $\begin{array}{l}\text { Homemade } \\
\text { coffee }\end{array}$ \\
\hline
\end{tabular}




\begin{tabular}{|l|l|l|l|l|l|}
\hline $\begin{array}{l}\text { Filtering the } \\
\text { ground coffee }\end{array}$ & Drying tunnel & $\begin{array}{l}\text { Turning the } \\
\text { beans }\end{array}$ & Nature & & $\begin{array}{l}\text { Coffee } \\
\text { products }\end{array}$ \\
\hline $\begin{array}{l}\text { Experiential } \\
\text { learning }\end{array}$ & & $\begin{array}{l}\text { Removing } \\
\text { shells }\end{array}$ & Mountains & & \\
\hline Educational & & $\begin{array}{l}\text { Coffee } \\
\text { grinding }\end{array}$ & $\begin{array}{l}\text { Local } \\
\text { tradition }\end{array}$ & & \\
\hline Coffee tasting & & $\begin{array}{l}\text { Coffee } \\
\text { roasting }\end{array}$ & Forest & & \\
\hline Drinking coffee & & $\begin{array}{l}\text { Traditional } \\
\text { method }\end{array}$ & Countryside & & \\
\hline
\end{tabular}

Similarities are observed in the themes from both data types, with five themes common to both, namely coffee experience, coffee production process, place, sustainability and tourism experience. Community and tourism infrastructure were themes unique to text data, and coffee farm was a unique theme to photo data. In observing these themes, three over-arching issues become evident, the coffee tourism experience, the place, and the overall tourism offering.

\subsection{Coffee tourism experience}

The coffee tourism experience considers the themes of coffee experience, which points to the visitors' experience relating to coffee; coffee production process, which outlines each step in the production process which tourists experienced; and the coffee farm, including the infrastructure that was part of the visit. This also includes elements of sustainability and community, which were key aspects of the coffee experience from the farm visited, however, evidence suggests that this was a unique experience in the Salento region, where coffee tourism has seen considerable growth in recent years, becoming a popular destination as part of a visit to Colombia. The unique nature of this specific tour is highlighted by the local tourism provider, who pointed to the extent of non-local ownership of tourism providers in Salento, which impacts the economic benefit from coffee tourism to the local community.

"Fifty percent of Salento's tourism infrastructure-hostals, bars, guide companiesare owned by foreigners and $40 \%$ by non-local Colombians who expropriate their earnings and pay little taxes. Only $10 \%$ is owned by Salentinos. Salento's bustling tourism barely benefits local communities." (Tourism provider)

The unique offering of this tour adheres to the tourists' interest in authentic coffee experiences (Kleidas \& Jolliffe, 2010). A significant aspect of this tour was the interactive and educational nature of the tour, focussing on the entire coffee production process, from picking the fruit to making a cup of coffee. This holistic all-day experience differed to other offerings in the area, which were advertised as lasting between 40 minutes to 2 hours.

"The participation that is encouraged as part of the tour is a valuable experience, and one that differs from many of the other shorter ( 40 minutes) tours on offer in the area. The informative aspect of the tour was also interesting, as he showed his passion and knowledge for organic and regenerative practice." (Reflective diary) 
Another unique aspect of this offering was the traditional methods employed on the farm, using manual equipment, leading to the handmade production of coffee. This aligns with the ethos of the farm in preserving traditional methods, rural conservation, and maintaining a self-sustainable lifestyle. The farm is $100 \%$ organic and built on traditions of coffee farming passed down for generations in the local community. Figure 1 outlines the manual process of producing the coffee, using traditional equipment and methods, which are more laborious, but follow local traditions of coffee farming.

Figure 1: Tourist participation in de-pulping the coffee fruit

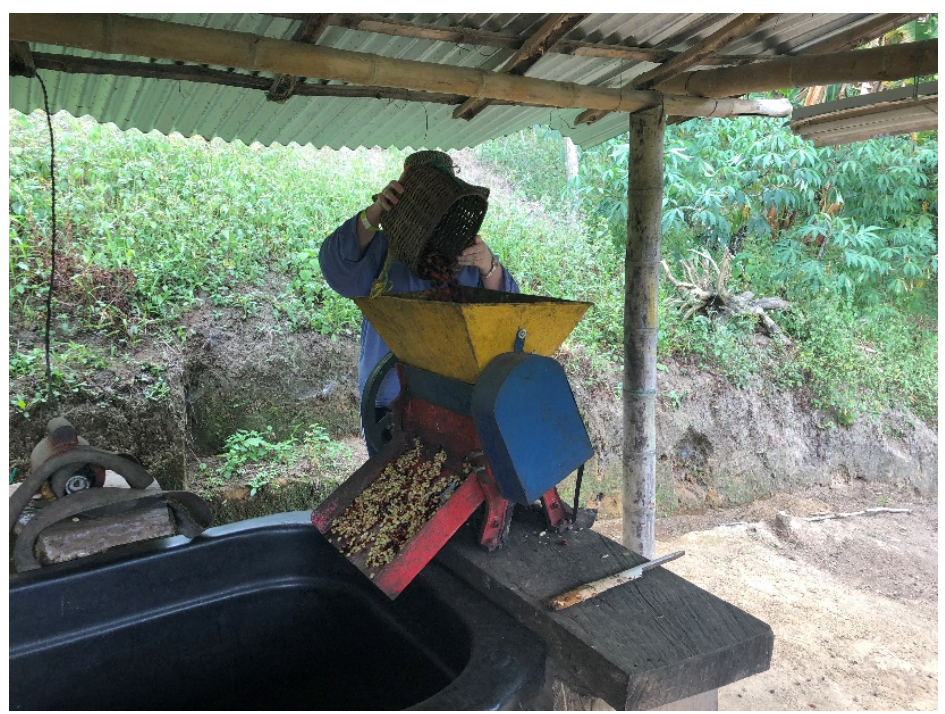

The unique and exclusive experience from the observed coffee visit symbolises the aspect of 'otherness' (MacCannell, 1973) in the coffee tourism offering, acting as a marked exception from other coffee tours in the local area, which cater for the 'mass' tourism market. While Salento is a town that is focussed on coffee tourism, most tours are aimed at larger visitor numbers. The tour observed in this research provided a distinguished experience from alternative tours, as its offering was based on a unique and personalised cultural experience of traditional coffee production, based on sustainability and authenticity, and centred on community values. Given the various motivations for tourists to engage in coffee tourism (Kleidas \& Jolliffe, 2010), the different experiences on offer in the Salento region have the potential to cater for various coffee tourism motivations, ranging from those with an interest in coffee, to tourists who value local heritage, sustainability, and authentic experiences.

\subsection{Place}

The emphasis on sustainability on the observed coffee farm echoes Woyesa and Kumar's (2020) findings for the potential for coffee tourism growth in Ethiopia, with a view to promoting local conservation and sustainable livelihoods. Place aspects are significant in the offering of the farm, both in relation to the terroir of the coffee product and the impact of coffee tourism on the local economy. The organic and traditional process of producing coffee is a significant aspect of the terroir of the product (Barham, 2003), based on the unique heritage to the local community, aligning with VRIN aspects of RBV theory (Barney, 1991), emphasising the close connections between coffee and place (Thorn \& Segal, 2007). The PGI 
status of Colombian Coffee confirms the terroir of the product and enhances the reputation of the product, which differs to the concerns expressed by Anbalagan and Lovelock (2014) in relation to Rwanda. Although Colombia may share similar historical issues of conflict as Rwanda, the reputation for coffee, particularly due to the PGI status of Colombian Coffee and the UNESCO World Heritage status of the Paisaje Cultural Cafetero, and increasing visitor numbers to the country (World Bank, 2020), put Colombia in a stronger position to take advantage of coffee tourism. Additionally, the Juan Valdez brand, evident in coffee products and a chain of Colombian coffee shops, enhances the coffee culture of Colombia (Muñiz Martínez, 2016). These highlight the unique qualities of Colombian coffee (Oberthür et al., 2011), which act as a place identifier in promoting the region's identity (Everett, 2016). This is also an appealing factor in attracting tourists to the area, as expressed by two tourists on the visit:

"The work of the community is very important. It is good to see a focus on sustainability and uniting small businesses. This is an important part of the conservation of the area and this is a valuable authentic experience." (Tourist 1)

The emphasis on community was prominent from the coffee producer and the tourism provider, as they recognise that tourism is developing in the Salento area, as it is across the Eje Cafetero, therefore they understand the need to take advantage of this, but in a way that corresponds with their community ethos.

"Without business initiatives or cooperation, hordes of tourists were literally passing by, from touristy Salento to the touristy coffee farms that have marketing schemes and non-local owners...We have developed authentic tours with locals to ensure that we can provide tourists with a unique offering that can also benefit this small community." (Tourism provider)

The tourist provider acknowledges they have less resources than other farms in the area that cater for larger numbers of tourists, however, they benefit from their unique tourism offering in providing a personalised, authentic and holistic coffee experience. This aligns with their more remote rural surroundings, away from the bustle of the town, where the natural surroundings add to the interest in conservation, ecological awareness and self-sustainability.

Partnerships with key community members, including local tourism providers, are important in seeing benefits in a sustainable manner, as seen by Woyesa and Kumar (2020) in coffeeproducing communities in Ethiopia, and Lyon (2013) in Guatemala, who pointed to coffee tourism as an affirmation of local indigenous identity. The local community recognise the opportunity for growth through tourism (Kleidas \& Jolliffe, 2010), which would lead to an increase in sales, potentially international sales. However, coffee tourism activities are a means of supplementing income for these communities (Lyon, 2013; Woyesa \& Kumar, 2020).

\subsection{Tourism experience}

The emergence of places such as Salento as tourist destinations underlines the demand for coffee tourism and the opportunities for places in the Global South to capitalise on tourism opportunities from their coffee production (Kleidas \& Jolliffe, 2010). This implies that the 
infrastructure for tourism, which was a barrier considered by Anbalagan and Lovelock (2014) in relation to Rwanda, is in place in Salento, both in terms of the tourism facilities available in the town, and infrastructure to travel to the area. Tourist 3 pointed to the accessibility of travelling to Salento as part of a tour of Colombia:

"It was very easy to get here. We travelled from Bogota and the flight was only 25 minutes to Pereira. The journey from Pereira was more challenging, as we had to find the bus station and how to get to Salento. We also found that people didn't speak English, but we managed to get here." (Tourist 3)

Language was observed by the researcher, not only in the Salento area, but across Colombia more broadly: "One thing we noticed about Colombia is that few people speak English, and having some Spanish is essential in asking for directions or finding your way" (Reflective diary). This is surprising considering increasing numbers of international tourists visiting Colombia. Spanish was the language of the coffee experience, with two tourists unable to speak Spanish. This was not a problem due to the interactive and experiential nature of the visit, with the coffee producer managing to demonstrate different aspects of the coffee production process. One tourist who did speak Spanish was able to provide translations.

The tourism infrastructure is supported by Colombia's reputation for coffee, evident through its PGI status (Oberthür et al., 2011), and UNESCO World Heritage status of the Paisaje Cultural Cafetero. Despite the developing tourism infrastructure in Salento, the tourism provider expressed concerns about external ownership within the local tourism infrastructure, including hostels, bars and restaurants. Therefore, the collaborative approach taken by local community members is an important part of the authentic offering in the area, to ensure that tourists can experience the true heritage of the community. As a cultural experience, food is an important part of this authenticity (Ellis et al., 2018), and the availability of local food was evident in Salento. This is significant for the tourism offering of a place, due to close connections between food and place heritage (Tregear et al., 1998).

\section{Conclusion}

Findings from this research show the potential for coffee tourism in Colombia within the Eje Cafetero, since there is already good travel infrastructure in place in facilitating access to the area, and it has established itself as a destination on tourism routes around Colombia. An increasing body of research points to tourism opportunities in Colombia, particularly relating to food and cultural heritage (Bassols, 2019; Bassols \& Leicht, 2020; Muñiz Martínez, 2016; Stahl et al., 2019). Compared to other potential coffee tourism destinations, Colombia has established a reputation for itself due to a PGI status for the product and UNESCO World Heritage status for the place. These factors have helped develop a coffee tourism offering to cater for different motivations, including those interested in a general coffee tourism experience, and those interested in the unique local heritage of coffee production. Considering RBV theory (Teece, 2007), findings imply that places can develop a competitive advantage by leveraging unique place resources. This can be enhanced by a strategic vision to build on the reputation of key attributes, coffee in this case, to promote tourism opportunities. The terroir of Colombian coffee distinguishes it from other coffee products, 
enhanced by its PGI status, UNESCO World Heritage status, and Juan Valdez brand, which strengthens the authenticity and heritage of Colombian coffee (Muñiz Martínez, 2016).

Although the transport infrastructure within Colombia allows for tourists to travel easily to the coffee area, findings point to issues of ownership of tourist businesses in the coffee area. Concern for this was expressed by the local tourism provider, who has taken action in developing partnerships with local accommodation providers and coffee producers, who share the same ethos for sustainability and supporting the local economy. Such partnerships between local stakeholders could develop unique coffee tourism experiences that emphasise the cultural heritage of the coffee area. These experiences provide differentiated tourist offerings within the area, compared to mass-focussed offerings often provided by externallyowned companies. Ownership and unevenness within the tourism provision in the coffee area is an issue for future research, to understand its impact on the local tourism economy.

Implications for practice from this research underline the value in forming close relationships between local tourism stakeholders, which could provide mutual benefits in the promotion of different local tourism offerings, whether accommodation, coffee producers or restaurants; and benefits to the local economy, by ensuring that tourism spending with local attractions would remain in the area. Given the small scale of tourism businesses investigated in this area, the development of local partnerships would provide a stronger voice in ensuring their issues could be raised more effectively. The creation of partnerships around local tourism businesses that emphasise sustainability and traditional methods of coffee production could also enhance the reputation of Colombia and the coffee area for its coffee heritage, reinforced by the PGI status, UNESCO World Heritage location, and Juan Valdez brand, which underline the quality and tradition of Colombian coffee. Additionally, the strength and growth of these local partnerships could include additional local producers and tourism businesses, which could in turn strengthen tourism experiences. This could be an area for future research, in developing a deeper understanding of opportunities for growth on both the supply and demand side of tourism in the local area.

Conducted in August 2019, a limitation of the research is that it does not account for changes in tourism due to the Coronavirus pandemic, which has disrupted opportunities for travel. It is unclear how long this impact would have on the tourism industry, and could lead to the closure of tourism attractions, with smaller-scale business most at risk. The coffee farm observed in this research could potentially be impacted in the reduction of its tourism capacity, as well as possible limits to its production and coffee sales. On the other hand, the pandemic may lead to tourists seeking a more unique experience, therefore attractions offering differentiated and personalised experiences could be more desired in future. Research would be beneficial to understand the impact of this on smaller-scale tourism businesses, and how this may change in the longer-term.

The ethnographic approach of this study makes a valuable methodological contribution to tourism research, particularly in supporting an emerging method of evaluating lived tourism experiences. As an exploratory study, further research on this context would provide deeper understandings about opportunities for growth in coffee tourism in Colombia. Indeed, further empirical research on different locations would enhance knowledge about coffee tourism 
experiences more broadly. The author echoes calls from Tribe (2004) in seeking new approaches to research, particularly the sentiments of those who advocate auto-ethnography in observing tourism experiences. As a lesser-used method, future research using autoethnographic methods should underline how rigour is maintained in all processes.

\section{References}

Anbalagan, K., \& Lovelock, B. (2014). The potential for coffee tourism development in Rwanda - Neither black nor white. Tourism and Hospitality Research, 14(1-2), 81-96.

Anderson, L. (2006). Analytic autoethnography. Journal of Contemporary Ethnography, 35(4), 373-395.

Barham, E. (2003). Translating terroir: the global challenge of French AOC labeling. Journal of Rural Studies, 19(1), 127-138.

Barney, J. B. (1991). Firm Resources and Sustained Competitive Advantage. Journal of Management, 17(1), 99-120.

Bassols, N. (2019). Evolving Iconization and Destination Building: The Example of Cartagena, Colombia. Tourism Planning \& Development, 16(3), 334-352.

Bassols, N., \& Leicht, T. (2020). Place marketing, evolutionary theories and the management of multifaceted destinations: Cartagena, Colombia, as a study case. Tourism and Hospitality Research.

Bowen, R., \& Bennett, S. (2020). Selling places: a community-based model for promoting local food. The case of Rhondda Cynon Taf. Journal of Place Management and Development, 13(2), 215-228.

Braun, V., \& Clarke, V. (2006). Using thematic analysis in psychology. Qualitative Research in Psychology, 3(2), 77-101.

Broadway, M. J. (2017). 'Putting Place on a Plate'along the West Cork Food Trail. Tourism Geographies, 19(3), 467-482.

Bujdosó, Z., \& Szûcs, C. (2012). Beer tourism-from theory to practice. Academica Turistica, 5(1), 103-111.

Cresswell, T. (2004). Place: A Short Introduction. Wiley, Chichester.

Creswell, J. W., \& Plano Clark, V. L. (2011). Designing and Conducting Mixed Methods Research. SAGE Publications, Thousand Oaks, CA.

Diaz Hermelo, F., \& Vassolo, R. (2012). How much does country matter in emerging economies? Evidence from Latin America. International Journal of Emerging Markets, 7(3), 263-288.

Du Rand, G. E., \& Heath, E. (2006). Towards a framework for food tourism as an element of destination marketing. Current Issues in Tourism, 9(3), 206-234.

Ellis, A., Park, E., Kim, S., \& Yeoman, I. (2018). What is food tourism? Tourism Management, $68,250-263$. 
Everett, S. (2016). Food and Drink Tourism: Principles and Practice. SAGE Publications, London.

Garrod, B. (2007). A snapshot into the past: The utility of volunteer-employed photography in planning and managing heritage tourism. Journal of Heritage Tourism, 2(1), 14-35.

Getz, D., \& Brown, G. (2006). Critical success factors for wine tourism regions: a demand analysis. Tourism Management, 27(1), 146-158.

Hall, C. M., \& Sharples, L. (2004). The consumption of experiences or the experience of consumption? An introduction to the tourism of taste. In Food tourism around the world (pp. 13-36). Routledge.

Jolliffe, L. (2010). Coffee culture, destinations and tourism. Channel View Publications, Bristol.

Jardón, C. M., \& Martos, M. S. (2012). Intellectual capital as competitive advantage in emerging clusters in Latin America. Journal of Intellectual Capital, 13(4), 462-481.

Jardón, C. M., \& Tañski, N. C. (2018). Place-based competitiveness in subsistence small businesses. Journal of Entrepreneurship in Emerging Economies, 10(1), 23-41.

Juan Valdez. (2020). Our History. https://www.juanvaldezcafe.com/en-us/our-brand/ourhistory/ [Accessed 26/08/2020]

Kleidas, M., \& Jolliffe, L. (2010). Coffee attraction experiences: A narrative sStudy. Turizam: Međunarodni Znanstveno-Stručni Časopis, 58(1), 61-73.

Knollenberg, W., Duffy, L. N., Kline, C., \& Kim, G. (2020). Creating competitive advantage for food tourism destinations through food and beverage experiences. Tourism Planning \& Development, 1-19.

Lyon, S. (2013). Coffee tourism and community development in Guatemala. Human Organization, 72(3), 188-198.

MacCannell, D. (1973). Staged authenticity: Arrangements of social space in tourist settings. American Journal of Sociology, 79(3), 589-603.

Molleda, J.-C., \& Roberts, M. (2008). The Value of "Authenticity" in "Glocal" Strategic Communication: The New Juan Valdez Campaign. International Journal of Strategic Communication, 2(3), 154-174.

Muñiz Martínez, N. (2016). Towards a network place branding through multiple stakeholders and based on cultural identities: The case of "The Coffee Cultural Landscape" in Colombia. Journal of Place Management and Development, 9(1), 73-90.

Oberthür, T., Läderach, P., Posada, H., Fisher, M. J., Samper, L. F., Illera, J., Collet, L., Moreno, E., Alarcón, R., \& Villegas, A. (2011). Regional relationships between inherent coffee quality and growing environment for denomination of origin labels in Nariño and Cauca, Colombia. Food Policy, 36(6), 783-794.

Pink, S. (2006). The future of visual anthropology: Engaging the senses. Taylor \& Francis, London. 
Pink, S. (2013). Doing visual ethnography. Sage, London.

Plummer, R., Telfer, D., Hashimoto, A., \& Summers, R. (2005). Beer tourism in Canada along the Waterloo-Wellington ale trail. Tourism Management, 26(3), 447-458.

Relph, E. C. (1976). Place and placelessness. Pion Limited, London.

Ritzer, G. (1992). The McDonaldization of society. Pine Forge Press, Newbury Park, CA.

Scarles, C. (2010). Where words fail, visuals ignite: Opportunities for Visual Autoethnography in Tourism Research. Annals of Tourism Research, 37(4), 905-926.

Shepherd, J., Laven, D., \& Shamma, L. (2020). Autoethnographic journeys through contested spaces. Annals of Tourism Research, 84, 103004.

Sims, R. (2009). Food, place and authenticity: local food and the sustainable tourism experience. Journal of Sustainable Tourism, 17(3), 321-336.

Stahl, P. G., Tjandra, N. C., Feri, A., \& Marshall, K. (2019). Beer Brand word-of-mouth drivers in Colombia: A qualitative exploration. Transnational Marketing Journal, 7(2), 161-186.

Statista. (2019). World's largest coffee producing countries in 2018. https://www.statista.com/statistics/277137/world-coffee-production-by-leadingcountries/ [Accessed 26/08/2020]

Statista. (2020). Coffee consumption worldwide from 2012/13 to 2018/19. https://www.statista.com/statistics/292595/global-coffee-consumption/ [Accessed 26/08/2020]

Teece, D. J. (2007). Explicating dynamic capabilities: the nature and microfoundations of (sustainable) enterprise performance. Strategic Management Journal, 28(13), 13191350.

Thorn, J., \& Segal, M. (2007). The Coffee Companion: A Conoisseur's Guide (2nd ed.). Running Press, Philadelphia, PA.

Tregear, A., Kuznesof, S., \& Moxey, A. (1998). Policy initiatives for regional foods: some insights from consumer research. Food Policy, 23(5), 383-394.

Tregear, A., Török, Á., \& Gorton, M. (2015). Geographical indications and upgrading of smallscale producers in global agro-food chains: A case study of the Makó Onion Protected Designation of Origin. Environment and Planning A, 48(2), 433-451.

Tribe, J. (2004). Knowing about tourism: epistemological issues. In J. Phillimore \& L. Goodson (Eds.), Qualitative research in tourism. Ontologies, epistemologies and methodologies (pp. 46-62). Routledge, Abingdon.

UNWTO. (2020). World Tourism Barometer and Statistical Annex, January 2020 (Vol. 18, Issue 1). World Tourism Organization. https://doi.org/10.18111/wtobarometereng.2020.18.1.1 [Accessed 26/08/2020]

World Bank. (2020). International tourism, number of arrivals - Colombia. https://data.worldbank.org/indicator/ST.INT.ARVL?locations=CO [Accessed 26/08/2020] 
Woyesa, T., \& Kumar, S. (2020). Potential of coffee tourism for rural development in Ethiopia: a sustainable livelihood approach. Environment, Development and Sustainability, 1-18.

Yılmaz, B., Acar-Tek, N., \& Sözlü, S. (2017). Turkish cultural heritage: a cup of coffee. Journal of Ethnic Foods, 4(4), 213-220. 